\title{
The Water Quality and Nutrients Status in the Dungun River Basin, Terengganu
}

\author{
R. Uning ${ }^{1}$, S. Suratman ${ }^{1 *}$, E. A. Bedurus ${ }^{1}$, F. A. M. Nasir ${ }^{1}$, T. H. Seng ${ }^{1}$, M. T. Latif ${ }^{2}$ and R. Mostapa ${ }^{3}$ \\ ${ }^{1}$ Institute of Oceanography and Environment, Universiti Malaysia Terengganu, 21030 Kuala Nerus, Terengganu, \\ Malaysia \\ ${ }^{2}$ Department of Earth Sciences and Environment, Faculty of Science and Technology, Universiti Kebangsaan Malaysia,
} 43600 Bangi, Selangor, Malaysia

${ }^{3}$ Environmental Tracer Application Group, Malaysian Nuclear Agency Bangi, 43000 Kajang, Selangor, Malaysia

\begin{abstract}
This study investigated the spatial variation of nitrogen (N)-based and phosphorus (P)-based nutrients together with water quality parameters (temperature, $\mathrm{pH}$, dissolved oxygen, biological oxygen demand, chemical oxygen demand and total suspended solids) in the Dungun River basin, Terengganu. The Water Quality Index (WQI) of the river was applied according to the Malaysian Department of Environment (DOE-WQI) and classified based on the Malaysian National Water Quality Standard (NWQS). Results showed that the major source of nutrients and water quality deterioration in the basin was most likely due to the effluent discharged from the nearby palm oil factory. The overall WQI mean value obtained was $85.44 \%$, which indicated that the Dungun River basin was in a clean condition and categorised into Class II based on the NWQS classification. The overall mean mass $\mathrm{N}: \mathrm{P}$ ratio was 19.8:1 which indicated that the algal growth was generally controlled by the P-based nutrients. Based on this study, it is suggested continuous monitoring necessary to be carried out for proper management of this river basin.
\end{abstract}

Keywords: N-based nutrients; P-based nutrients; Water Quality Index; National Water Quality Standard; Dungun River basin

\section{INTRODUCTION}

Rivers are beneficial to the human population and to the natural environment. For human purposes, rivers can serve as a food source, a recreational place, a water supply for agricultural irrigation, and transportation. Rivers also serve as habitats for aquatic life and are sources of water for wildlife in the natural environment. However, the functions of a river may start to degrade as development of an area nearby may directly and indirectly affect the water quality of the river (i.e., land use for agriculture) (Binh Thanh et al., 2020). The excess usage of fertilisers and pesticides in agricultural activities such as palm oil plantations and paddy fields may lead to nutrient inputs to the river, especially of nitrogen $(\mathrm{N})$-based and phosphorus (P)-based nutrients (Navarrete et. al., 2018; Suratman et al., 2004). Aquatic animal excretion from aquaculture activity can also contribute to nutrient input (Kawasaki et. al., 2016; Ling et al., 2013). The increment of these nutrients in the water body may trigger excessive algae growth, which may cause the slow destruction of the habitat of the aquatic life in that area (Ying et al., 2012).

The water quality status of a river can be examined using the Water Quality Index (WQI). This is to provide a simple and robust tool for top management division or decision makers on the quality and potential uses of a given water body (Bordalo et al., 2006). The water quality of Malaysian rivers was calculated according to the Malaysian Department of Environment Water Quality Index (DOE-WQI) and categorised according to the Malaysian National Water Quality Standard (NWQS) (DOE, 2006). This NWQS is a standard that defined the quality of water according to the 
beneficial uses of the body of water, which designated classes is recommended for a specific use provided it falls within the specified range. The definition of each class is shown in Table 1 (DOE, 2006).

Table 1. Definition of Classes for NWQS (DOE, 2006)

\begin{tabular}{|c|c|}
\hline Class & Uses \\
\hline Class I & $\begin{array}{l}\text { Conservation of natural environment } \\
\text { Water Supply } 1 \text { - Practically no treatment } \\
\text { necessary (except by disinfection or boiling } \\
\text { only) } \\
\text { Fishery } 1 \text { - Very sensitive aquatic species }\end{array}$ \\
\hline $\begin{array}{c}\text { Class } \\
\text { IIA }\end{array}$ & $\begin{array}{l}\text { Water Supply II - Conventional treatment } \\
\text { required } \\
\text { Fishery II - Sensitive aquatic species }\end{array}$ \\
\hline $\begin{array}{c}\text { Class } \\
\text { IIB }\end{array}$ & Recreational use with body contact \\
\hline Class III & $\begin{array}{l}\text { Water Supply III - Extensive treatment } \\
\text { required } \\
\text { Fishery III - Common of economic value, and } \\
\text { tolerant species; livestock drinking }\end{array}$ \\
\hline Class IV & Irrigation \\
\hline Class V & None of the above \\
\hline
\end{tabular}

Dungun River Basin which is located in the east coast of Peninsular Malaysia is one of the important riverine input sources that influence the coastal region primary productivity (Hee et al., 2020). Therefore, an assessment on the Dungun River Basin water quality is of utmost important. In this study, the determination of $\mathrm{N}$-based (nitrate, ammonia, urea, total dissolved $\mathrm{N}(\mathrm{TDN})$ and total particulate $\mathrm{N}$ (TPN)) and Pbased (orthophosphate, total dissolved P (TDP) and total particulate $\mathrm{P}$ (TPP)) nutrients and the respective water quality parameters (temperature $(\mathrm{T}), \mathrm{pH}$, dissolved oxygen (DO), biological oxygen demand (BOD), chemical oxygen demand (COD) and total suspended solids (TSS)) was carried out in the Dungun River basin, Terengganu. The results obtained were then compared to the Malaysian NWQS classification to determine the suitability and potential beneficial uses of the river. The WQI value of the Dungun River was calculated according to the DOE-WQI and categorised according to the NWQS classification.

\section{MATERIALS AND METHOD}

The Dungun River basin is the main river in the Dungun district. The river's catchment area is approximately 1858 $\mathrm{km}^{2}$ and the riser is $110 \mathrm{~km}$ in length, flowing from its main tributaries such as the Telembuh, Lok, Kelmin, Loh and Perlis Rivers before reaching the South China Sea. There are several anthropogenic activities occurring along the Dungun River, such as recreational sites, agriculture, sand digging, a palm oil factory, and a water treatment plant. The study was conducted from March 2003 to July 2003, and the water samples were collected four times at one-month intervals from the basin. Sampling was not performed in April 2003 due to technical problems. Eight sampling stations were assigned in the Dungun River basin: six stations (D1, D2, D3, D4, D7, D8) were located on the main river and two stations (D5, D6) were located on one of its tributaries (the Telembuh River). The location of the sampling stations is shown in Figure 1. In addition, the land use of the study area is given in Figure 2. 


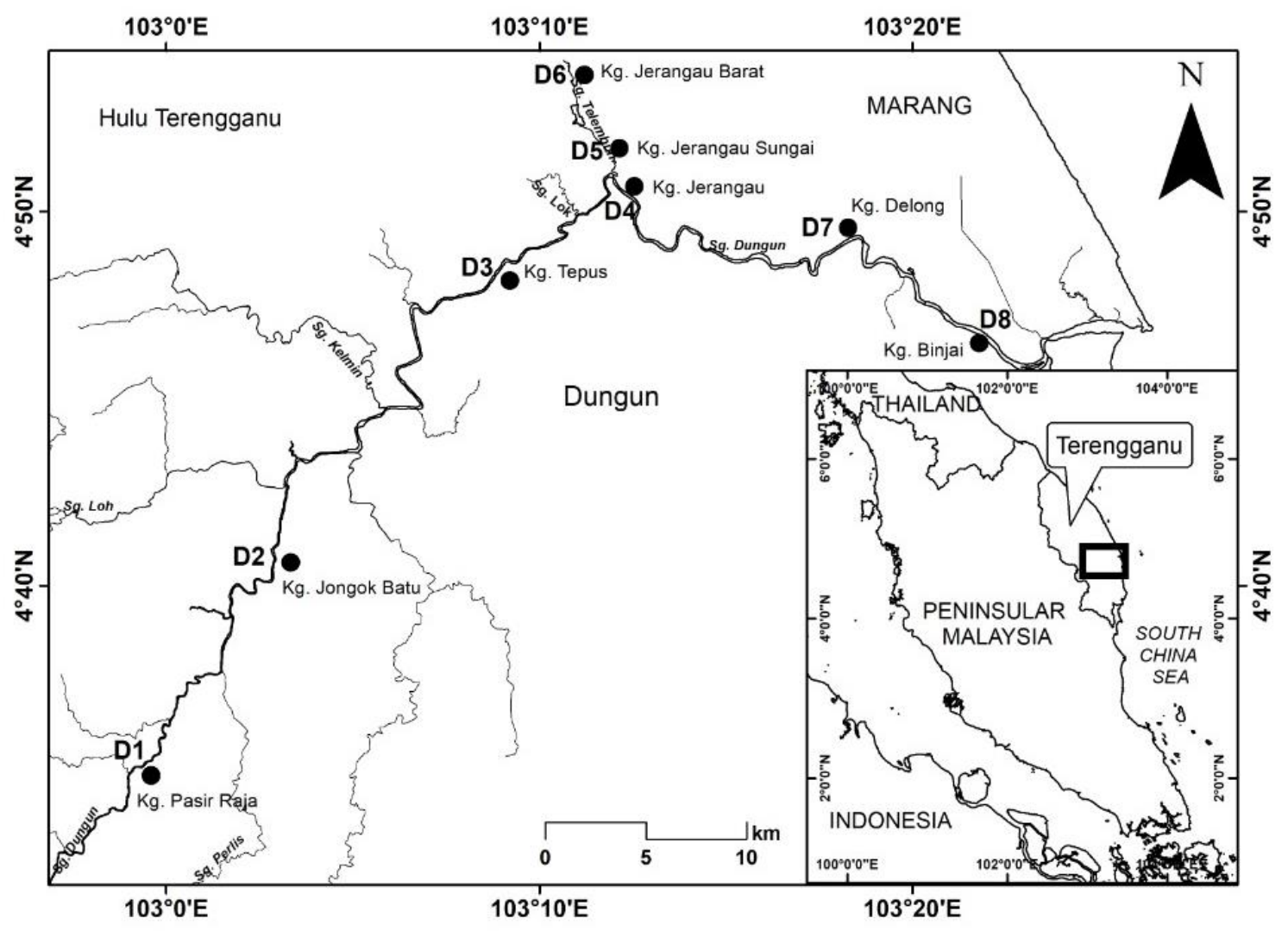

Figure 1. Location of the Dungun River basin and the sampling stations

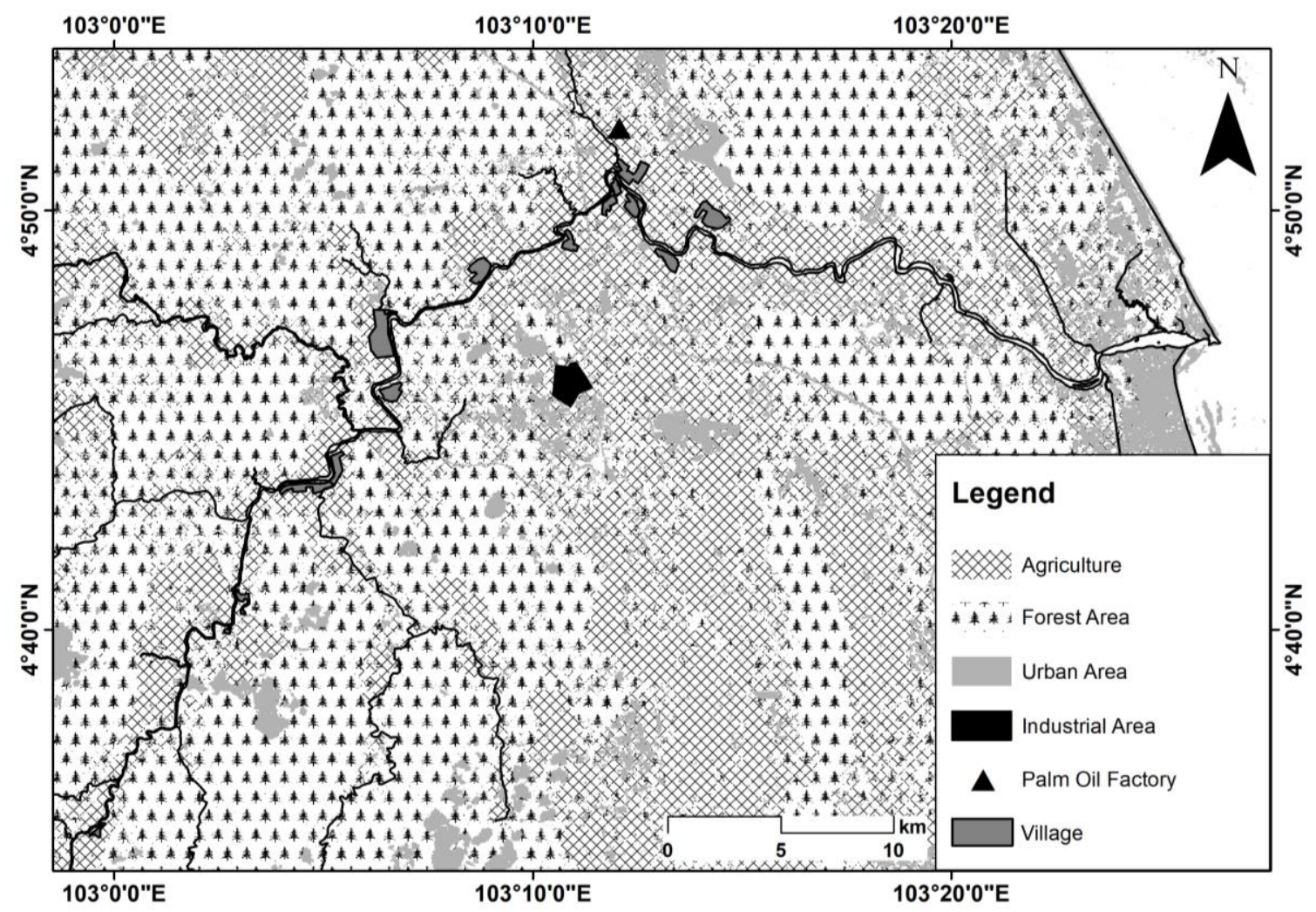

Figure 2. The land use of the study area in Dungun River basin 
Water samples were collected and stored according to the standard method (APHA, 1995). The high-density polyethylene (HDPE) bottles used in this sampling were soaked in $10 \%$ hydrochloric acid for three days to remove all contaminants from the bottles, and then rinsed with distilled water. The YSI multi-parameter was calibrated in the laboratory prior to field sampling according to the manufacturer's recommendation. The water samples were collected at a depth of $1 \mathrm{~m}$ below the water surface; at the shallow sites, the water samples were collected just above the riverbed. Van Dorn water sampler was employed to collect all water samples before stored in HDPE bottles. Then, the samples were immediately kept in an icebox for preservation purposes and transported to the laboratory for analysis.

For the determination of dissolved nutrients and TSS, the water samples were filtered through $0.45 \mu \mathrm{m}$ cellulose acetate membrane filters in the laboratory immediately after sampling. For the analysis of total particulate nutrients, urea, BOD and COD, no filtration of samples is needed. All filtered and unfiltered water samples were preserved in a freezer at $20{ }^{\circ} \mathrm{C}$ until further analysis, except for BOD (refrigerated at $4{ }^{\circ} \mathrm{C}$ ) and COD samples (acidified with $\mathrm{H}_{2} \mathrm{SO}_{4}$ to $\mathrm{pH}<2$ ). The samples were thawed to room temperature prior to analysis.

Physical parameters including $\mathrm{T}, \mathrm{pH}$ and $\mathrm{DO}$ were measured in situ using the YSI multi-parameter data logger. For the BOD parameter, the analysis was completed using the APHA standard method (APHA, 1995). The BOD bottles were pre-wrapped with aluminium foil and the samples were incubated inside the bottles at $20{ }^{\circ} \mathrm{C}$ for 5 days. Determination of TSS and COD parameters was also achieved according to the APHA standard method (APHA, 1995). Water quality parameters measured including DO, BOD, COD, ammonia, TSS, and $\mathrm{pH}$ were used to calculate the WQI (Tables 2 \& 3). Analyses of TDN, TPN, urea, ammonia and nitrate were determined based on the method used by Grasshoff et al. (1983). Meanwhile, for TPP and TDP, the samples underwent wet potassium persulfate $\left(\mathrm{K}_{2} \mathrm{~S}_{2} \mathrm{O}_{8}\right)$ oxidation (at $121{ }^{\circ} \mathrm{C}$ for $30 \mathrm{~min}$ ) prior to analysis (Grasshoff et al., 1983). Then, the molybdenum blue method was used to analyse the TPP and TDP together with orthophosphate (Grasshoff et al., 1983).
Table 2. Water quality calculation based on Water Quality Index (WQI) (DOE, 2006)

\begin{tabular}{cc}
$\begin{array}{c}\text { DO subindex } \\
\text { (saturation \%) }\end{array}$ & \\
\hline$x \leq 8$ & SIDO $=0$ \\
$x \geq 92$ & SIDO $=100$ \\
$8<x<92$ & SIDO $=-0.395+0.03 x^{2}-0.0002 x^{3}$
\end{tabular}

\begin{tabular}{cc}
\hline $\begin{array}{c}\text { BOD }(\mathrm{mg} / \mathrm{L}) \\
\text { subindex }\end{array}$ & \\
\hline$x \leq 5$ & SIBOD $=100.4-4.23 x$ \\
$x>5$ & SIBOD $=108^{-0.055 x}-0.1 x$ \\
\hline COD (mg/L) & \\
subindex & SICOD $=-1.33 x+99.1$ \\
\hline$x \leq 20$ & SICOD $=103 \mathrm{e}^{-0.0157 x}-0.04 x$ \\
$x>20$ &
\end{tabular}

\begin{tabular}{|c|c|}
\hline $\begin{array}{c}\text { Ammonia, AN } \\
(\mathrm{mg} / \mathrm{L} \mathrm{N}) \\
\text { subindex }\end{array}$ & \\
\hline$x \leq 0.3$ & SIAN $=100.5-105^{x}$ \\
\hline $0.3<x<4$ & SIAN $=94 \mathrm{e}^{-0.573 x}-5|x-2|$ \\
\hline$x \geq 4$ & SIAN $=0$ \\
\hline
\end{tabular}

\section{TSS (mg/L)}

subindex

\begin{tabular}{cc}
\hline$x \leq 100$ & SITSS $=97.5 \mathrm{e}^{-0.00676 x}+0.05 x$ \\
$100<x<1000$ & SITSS $=71 \mathrm{e}^{-0.0016 x}-0.015 x$ \\
$x \geq 1000$ & SITSS $=0$ \\
\hline $\mathrm{pH}$ & \\
subindex & \\
\hline$x<5.5$ & $\mathrm{SIpH}=17.2-17.2 x+5.02 x^{2}$ \\
$x \leq x<7$ & $\mathrm{SIpH}=-242+95.5 x-6.67 x^{2}$ \\
$7 \leq x<8.75$ & $\mathrm{SIpH}=-181+82.4 x-6.05 x^{2}$ \\
$x \geq 8.75$ & $\mathrm{SIpH}=536-77 x+2.76 x^{2}$
\end{tabular}

WQI $=0.22 *$ SIDO + 0.19*SIBOD + 0.16*SICOD + 0.15*SIA $+0.16^{*}$ SITSS + $0.12 * \mathrm{SIpH}$

Table 3. Water quality classification based on Water Quality Index (WQI) (DOE, 2006)

\begin{tabular}{c|c|c|c}
\hline Parameter & \multicolumn{3}{|c}{ Index range } \\
\hline & Clean & Slightly polluted & Polluted \\
WQI & $81-100$ & $60-80$ & $0-59$ \\
\hline
\end{tabular}

Statistical analysis involved a one-way ANOVA test ( $a=0.05)$ for each sampling parameter to analyse the differences of mean concentrations between the stations. 


\section{RESULT AND DISCUSSION}

\section{A. Water Quality Parameters}

The mean values for water quality parameters are shown in Figure 3. A comparison of water quality parameters from other study areas in Terengganu is given in Table 4. The mean values of temperature for each station were not presented in this figure as the range is narrow, i.e., between 27.16 and $28.30^{\circ} \mathrm{C}$. This is most likely due to the heating effect from direct sunlight exposure, which depends on the time of sampling (9.30 am to $5.00 \mathrm{pm}$ ).

The range of the $\mathrm{pH}$ mean values was 5.27 to 6.26 , which reflected that the water was slightly acidic. The mean values also showed significant differences $(\mathrm{p}<0.05)$ among the stations. Generally, all the mean concentrations for each station fell into Class III, except for station D1 (Class II), which was located upstream of the river. According to Jonnalagadda and Mhere (2001), pH normally near to neutral or slightly alkaline for unpolluted streams. The lowest $\mathrm{pH}$ mean value was recorded at station D5 (5.27). It is believed that the excessive effluent discharge from the palm oil factory and the runoff from the palm oil plantation nearby increased the organic compounds in the river. The decomposition process of these organic compounds releases carbon dioxide into the river, which led to the decrement of the pH value (Effendi et. al., 2015; Suratman et al., 2009). The effluent is generally low in $\mathrm{pH}$ because of the organic acids produced in the fermentation process, usually in the range 4-5 (Rupani et al., 2010). For comparison, the range of $\mathrm{pH}$ mean values in Dungun River basin was similar to the Besut and Setiu River basins. However, the range was slightly higher in the Paka River basin while the range was even higher and wider for the Marang River basin. The higher and wider range of $\mathrm{pH}$ mean values for the Marang River basin was due to the influence of seawater, which has a higher $\mathrm{pH}$ value (Suratman \& Tahir, 2013).

Mean DO concentrations varied from 4.93 to $9.05 \mathrm{mg} / \mathrm{L}$ and an ANOVA single factor analysis indicated significant differences among the stations $(\mathrm{p}<0.05)$. All the DO mean concentrations at each station can be categorised into Class I, except for station D5 (Class III). The highest DO mean concentration was recorded at station D3 $(9.05 \mathrm{mg} / \mathrm{L})$ while the lowest was at station D5 $(4.93 \mathrm{mg} / \mathrm{L})$. The lowest mean concentration of DO at station D5 was due to the effluent discharge from the palm oil factory nearby which polluted the water body. Wastewater from the factory contains high organic compounds that decrease the DO concentration (Lata et al., 2002). This was because the DO was utilised to decompose the organic compounds in the water (Effendi et. al., 2015; Suratman et. al., 2006; Chapman, 1992). In the comparison of concentration ranges of DO, the Dungun River basin was higher than the Marang and Setiu River basins, and the Paka River basin showed a much wider range.
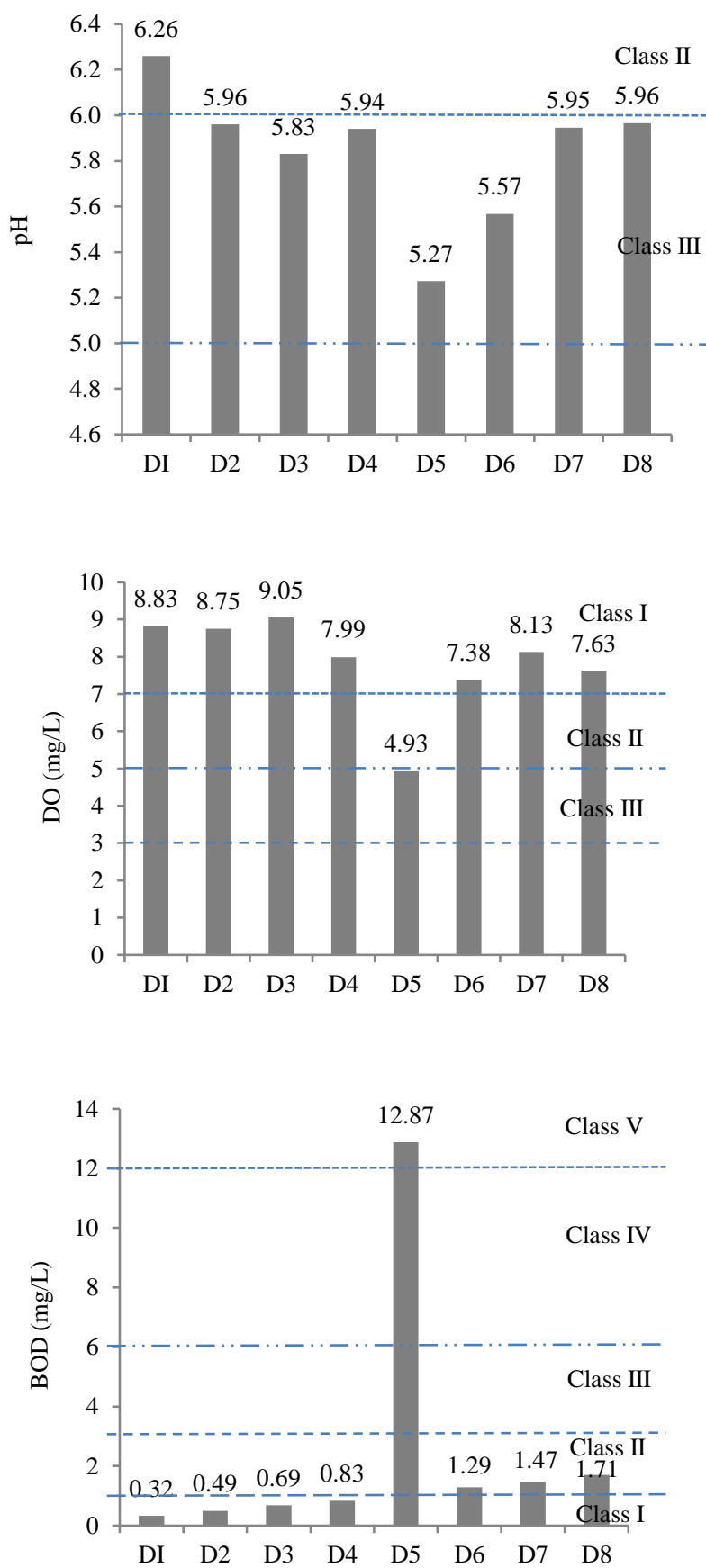

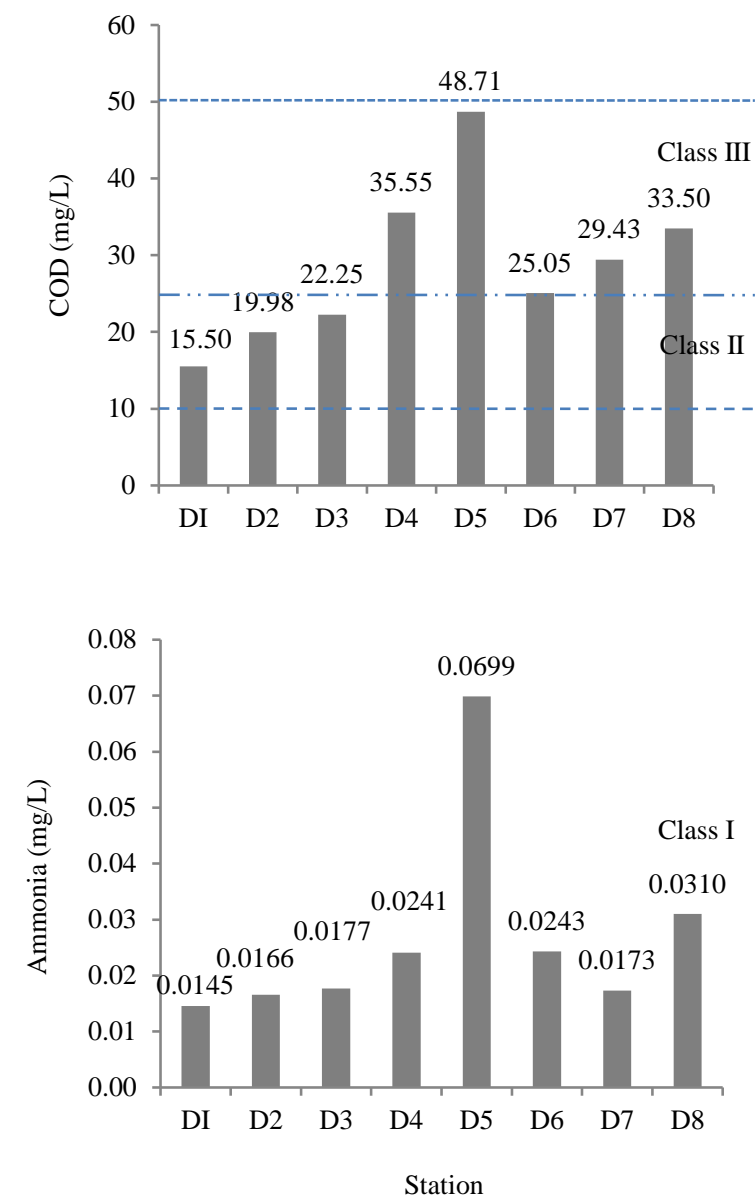

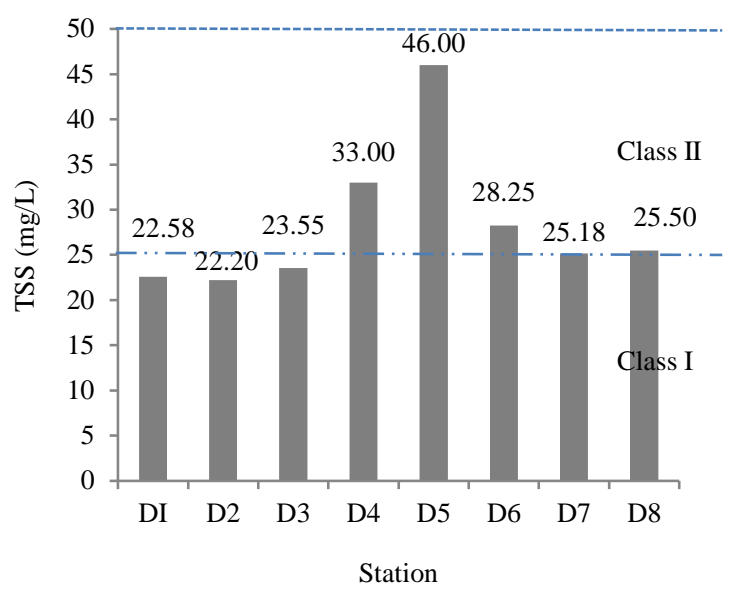

Figure 3. Distribution of mean values for water quality parameters at each station (Note: The dotted line on the bar chart represents range of values based on NWQS classification)

Table 4. Comparison of water quality parameters within selected river basins in Terengganu

\begin{tabular}{|c|c|c|c|c|c|c|c|}
\hline Location & pH & $\begin{array}{c}\text { DO } \\
(\mathrm{mg} / \mathrm{L}) \\
\end{array}$ & $\begin{array}{c}\text { BOD } \\
(\mathrm{mg} / \mathrm{L})\end{array}$ & $\begin{array}{c}\text { COD } \\
(\mathrm{mg} / \mathrm{L})\end{array}$ & $\begin{array}{c}\text { Ammonia } \\
\text { (mg/L) }\end{array}$ & TSS (mg/L) & Reference \\
\hline Dungun River & $5.27-6.26$ & $4.93-9.05$ & $0.32-12.87$ & $15 \cdot 50-48.71$ & $\begin{array}{l}0.0145^{-} \\
0.0699\end{array}$ & $22.20-46.00$ & $\begin{array}{c}\text { Present } \\
\text { study }\end{array}$ \\
\hline Paka River & $5.80-6.90$ & $1.90-8.40$ & $1.60-151.80$ & $16.30-523.10$ & $0.02-12.55$ & 19.30-120.00 & $\begin{array}{c}\text { Suratman et } \\
\text { al. (2009) }\end{array}$ \\
\hline Besut River & $5 \cdot 55^{-6.42}$ & $6.08-9.11$ & $0.10-1.90$ & $5.00-91.00$ & $0.02-0.14$ & $6.00-108.00$ & $\begin{array}{c}\text { Suratman et } \\
\text { al. (2006) }\end{array}$ \\
\hline Setiu River & $5.42-6.30$ & $4.19-7.97$ & $0.92-3.66$ & $4 \cdot 79-19 \cdot 76$ & $0.04-0.24$ & $0.77-5.19$ & $\begin{array}{l}\text { Zaideen et } \\
\text { al. (2017) }\end{array}$ \\
\hline Marang River & $5.90-8.20$ & $3 \cdot 50-7 \cdot 50$ & $0.40-1.30$ & $4.00-50.20$ & $\begin{array}{c}0.016- \\
0.161\end{array}$ & $0.30-20.4$ & $\begin{array}{c}\text { Suratman } \\
\text { and Tahir } \\
(2013)\end{array}$ \\
\hline
\end{tabular}

In the study, BOD mean concentrations ranged from 0.32 to $12.87 \mathrm{mg} / \mathrm{L}$. The ANOVA single factor analysis showed that the mean concentrations between sampling stations were significantly different $(\mathrm{p}<0.05)$. It can be observed that the mean concentrations of BOD increased from upstream to downstream of the river, except for station D5. Stations D1, D2, D3, and D4 were classified as Class I because these stations were located at upstream of the river and there was a lack of potential pollutant sources nearby. Meanwhile, stations D6, D7 and D8 fell into Class II. Station D6 was located upstream on the Telembuh River which leads to the Dungun River, while D7 and D8 were located downstream of the Dungun River. The highest BOD mean value was recorded at station D5 $(12.87 \mathrm{mg} / \mathrm{L})$ that has been classified into Class V. This high mean value can be related organic compounds which were released by the palm oil factory (Chungsiriporn et. al., 2006; Ahmad et al., 2003) and fertilisers/pesticides that leached from the palm oil plantation nearby into the 
river. These organic compounds were decomposed by microorganisms, which consumed oxygen in the water (Suratman et. al., 2006, Chapman, 1992). This result was supported by the DO data, as the DO mean value was the lowest at station D5. In comparison to other studies, the Dungun River basin had a higher range of BOD mean concentrations than the Besut, Setiu and Marang River basins, most likely due to the absence of palm oil effluent discharge into the Besut, Setiu and Marang rivers (Zaideen et. al., 2017; Suratman \& Tahir, 2013; Suratman et al., 2006). However, the range of BOD mean values in the Dungun River basin was much lower compared to the Paka River basin. The major contributor to the higher range of BOD mean values in the Paka River basin was most probably due to high volume of the palm oil effluent discharge into the river (Suratman et al., 2009).

For COD, the mean values varied from 15.50 to $48.71 \mathrm{mg} / \mathrm{L}$ and the single factor ANOVA test showed that the mean values between the stations were significantly different. The upstream stations (D1, D2, D3) were categorised as Class II while the other stations were classified as Class III. The highest COD mean value was recorded at station $\mathrm{D}_{5}$. The palm oil factory effluent discharged into the river contained many pollutants that cannot be biodegraded by the microorganisms (Suratman et. al., 2009; Chungsiriporn et al., 2006). This contributed to the highest COD mean value at station D5. Station D4 had the second highest COD mean value due to domestic waste that came from the village and runoff from the agriculture area that leached into the river. According to Ho et al. (2003), domestic waste contains organic compounds that cannot be biodegraded by microorganisms. The lowest COD mean value was recorded at station D1 due to a lack of pollution and human activities close by. In comparison with the Setiu River basin, the Dungun River showed higher ranges of COD mean concentrations. However, the Besut and Paka River basins showed higher COD mean values compared to the Dungun River, most likely because of the organic substances introduced into the Besut River during the monsoon season (Suratman et al., 2006) and the high volume of the palm oil effluent discharge into the Paka River (Suratman et al., 2009). Meanwhile, the range of COD mean values for the Dungun and Marang River basins were similar.
The mean values of ammonia at each sampling station ranged from 0.0145 to $0.0699 \mathrm{mg} / \mathrm{L}$ and the one-way ANOVA test showed significant differences of the mean values between the sampling stations $(\mathrm{p}<0.05)$. In this study, the ammonia mean concentrations for all sampling stations were classified as Class I. However, it can be observed that the mean values gradually increased from upstream to downstream of the Dungun River, with the exception of station D5. The highest ammonia mean value was recorded at station D5 and it is believed that the major contribution to this came from the effluent of the palm oil factory (Suratman et al., 2009) and the runoff that carried fertiliser residue from the nearby palm oil plantation into the river. For comparison, the Dungun River basin showed a lower range of ammonia mean values compared to the Paka, Besut, Setiu and Marang River basins.

The TSS mean values ranged from 22.20 to $46.00 \mathrm{mg} / \mathrm{L}$. The highest TSS mean concentration was recorded at station D5 (46.00 mg/L) while the lowest was at station D2 (22.20 $\mathrm{mg} / \mathrm{L}$ ). The upstream stations (D1, D2, D3) (Class I) showed relatively lower TSS mean values than the other stations (Class II). A one-way ANOVA test revealed that there was a significant difference $(\mathrm{p}<0.05)$ between stations for TSS mean values. Station D5 showed the highest TSS mean value and the major sources were thought to be the effluent from the palm oil factory and runoff from the palm oil plantation nearby. Station D4 also showed relatively high TSS content most probably due to soil erosion from agriculture and domestic waste disposal nearby. The lowest TSS concentration at station D2 was due to the lack of human activity in that area. In comparison with the results from other selected rivers, the range of TSS mean concentrations of the Dungun River basin was much higher than Setiu and Marang River basins. However, the TSS mean concentrations range for the Dungun River basin was much lower when compared to the Paka and Besut River basins. The higher TSS range in the Paka River basin was most likely due to the effluent discharge with high TSS content from the palm oil mill and soil erosion caused by the re-cultivation of palm oil plants (Suratman et al., 2009). Meanwhile, the major contribution of high TSS value in the Besut River basin was due to the domestic wastes originating from the town of Jertih and surface runoff together with soil erosion from the 
riverbank during the monsoon season (Suratman et al., 2006).

\section{B. Water Quality Index}

All the water quality parameters measured including $\mathrm{pH}, \mathrm{DO}$, BOD, COD, ammonia and TSS were used to calculate the WQI, and the results are shown in Figure 4. The obtained WQI ranged from $55.94 \%$ to $93.10 \%$. The furthest-upstream station (D1) showed the highest WQI value (93.10\%) while the lowest was at station D5 (55.94\%). According to the DOEWQI classification, station D5 is classified as a polluted site. However, the other stations were classified as clean areas (WQI $>81.00 \%$ ). In general, the water quality decreased from upstream to downstream locations of the river. Overall, the mean WQI value obtained was $85.44 \%$. According to the NWQS classification, the mean WQI value of Dungun River basin fell into Class II (WQI 76.6-92.7\%). Thus, the water quality status of the Dungun River basin can be considered clean.

Table 5 shows the comparison of WQI values obtained in the current study to selected river basins in Terengganu, Malaysia. The WQI was also calculated for the Besut River (90.1\%) (Suratman et al., 2006) and the Setiu River (84.0\%) (Zaideen et al., 2017) basins by previous studies; these rivers were also classified as clean rivers (Class II). However, it was different in the study conducted by Suratman et al. (2009) for the Paka River (72.4\%) and Suratman and Tahir (2013) for the Marang River (74.0\%) whereby the recorded WQI values indicating lower water quality and these rivers were classified as slightly polluted (Class III).

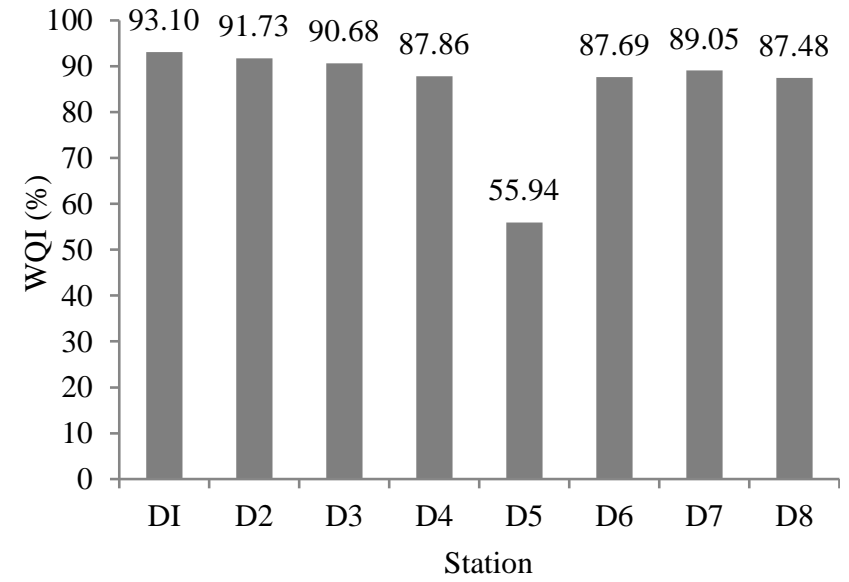

Table 5. Comparison of WQI value for selected river basins in Terengganu

\begin{tabular}{|c|c|c|c|c|}
\hline Location & $\begin{array}{c}\text { WQI } \\
\text { (\%) }\end{array}$ & Class & Status & Reference \\
\hline $\begin{array}{l}\text { Dungun } \\
\text { River }\end{array}$ & 85.4 & II & Clean & $\begin{array}{c}\text { Present } \\
\text { study }\end{array}$ \\
\hline $\begin{array}{l}\text { Paka } \\
\text { River }\end{array}$ & 72.4 & III & $\begin{array}{l}\text { Slightly } \\
\text { polluted }\end{array}$ & $\begin{array}{l}\text { Suratman } \\
\text { et al. } \\
(2009)\end{array}$ \\
\hline $\begin{array}{l}\text { Besut } \\
\text { River }\end{array}$ & 90.1 & II & Clean & $\begin{array}{l}\text { Suratman } \\
\text { et al. } \\
(2006)\end{array}$ \\
\hline $\begin{array}{l}\text { Setiu } \\
\text { River }\end{array}$ & 84.0 & II & Clean & $\begin{array}{l}\text { Zaideen et } \\
\text { al. (2017) }\end{array}$ \\
\hline $\begin{array}{c}\text { Marang } \\
\text { River }\end{array}$ & 74.0 & III & $\begin{array}{l}\text { Slightly } \\
\text { polluted }\end{array}$ & $\begin{array}{c}\text { Suratman } \\
\text { and Tahir } \\
(2013)\end{array}$ \\
\hline
\end{tabular}

Table 6. Mean, range and Malaysia NWQS classification for the Dungun River basin

\begin{tabular}{c|c|c|c}
\hline Parameter & Mean & Range & $\begin{array}{c}\text { NWQS } \\
\text { Classification }\end{array}$ \\
\hline $\mathrm{pH}$ & 5.84 & $\begin{array}{c}5.27- \\
6.26\end{array}$ & Class III \\
$\mathrm{DO}(\mathrm{mg} / \mathrm{L})$ & 7.84 & $\begin{array}{c}4.93- \\
9.05\end{array}$ & Class I \\
& & $0.32-$ & Class II \\
$\mathrm{BOD}$ & 2.46 & 12.87 & \\
$(\mathrm{mg} / \mathrm{L})$ & & $15.50-$ & Class III \\
$\mathrm{COD}$ & 28.75 & 48.71 & \\
$(\mathrm{mg} / \mathrm{L})$ & & $0.0145-$ & Class I \\
$\mathrm{Ammonia}$ & 0.0269 & 0.0699 & \\
$(\mathrm{mg} / \mathrm{L})$ & & $22.20-$ & Class II \\
TSS & 28.28 & 46.00 & \\
\hline
\end{tabular}

Table 6 depicted the information of mean value of water quality parameters of Dungun River Basin and classification according to NWQS for Malaysia, respectively. The results showed that the DO and ammonia fell into Class I, while BOD and TSS were classified as Class II. These classifications indicated that the river is suitable for water supply and recreational use with direct contact of the water body. However, COD and $\mathrm{pH}$ fell into Class III, which indicated that extensive treatment is required in order for the water to be supplied for human use.

Figure 4. The WQI values for each station 


\section{Distribution of N-based Nutrients}

Histograms based on the $\mathrm{N}$-based nutrient mean values at each station are presented in Figure 5. The distribution of $\mathrm{NH}_{3}$ mean values was discussed in the previous section. Across the sampling stations, the following range of mean concentrations were recorded: nitrate 50.13-155.96 $\mu \mathrm{g} / \mathrm{L} \mathrm{N}$, urea 17.13-38.18 $\mu \mathrm{g} / \mathrm{L} \mathrm{N}$, TDN 164.86-367.82 $\mu \mathrm{g} / \mathrm{L} \mathrm{N}$, and TPN 96.36-442.66 $\mu \mathrm{g} / \mathrm{L}$ N. Significant differences were observed based on the one-way ANOVA test on mean values between the sampling stations for all types of $\mathrm{N}$ compounds in this study $(\mathrm{p}<0.05)$. Station D5 had the highest mean concentration of each $\mathrm{N}$-species compared to other stations, i.e., nitrate $(155.96 \mu \mathrm{g} / \mathrm{L} \mathrm{N})$, urea $(38.18 \mu \mathrm{g} / \mathrm{L} \mathrm{N})$, TDN $(367.82 \mu \mathrm{g} / \mathrm{L} \mathrm{N})$ and TPN (442.66 $\mu \mathrm{g} / \mathrm{L} \mathrm{N})$. This was expected as D5 station was situated downstream of the Telembuh River where a palm oil factory was located, between Kampung
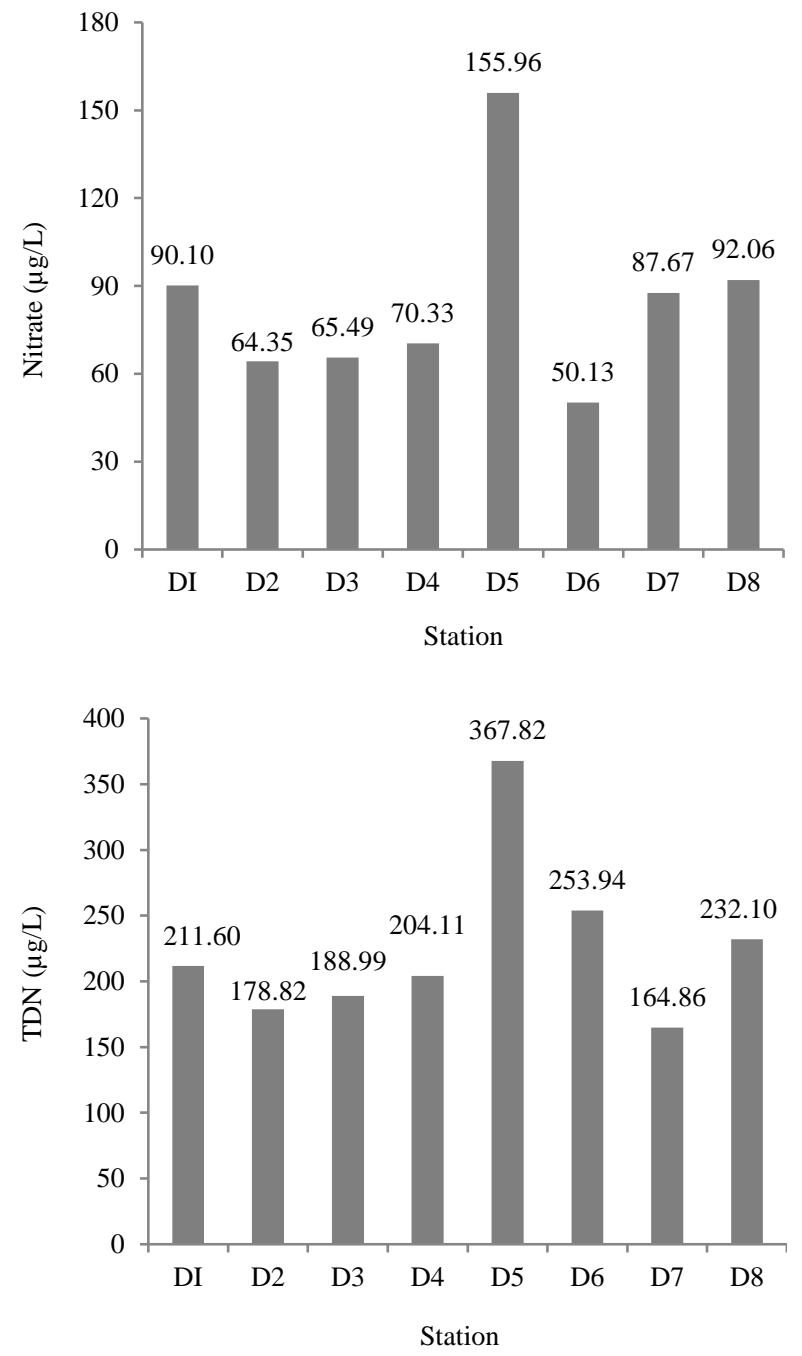

Jerangau Sungai (station D5) and Kampung Jerangau Barat (station D6). Thus, it is believed that the effluent from the factory had been released into the river and elevated the nutrient concentration.

Several researchers have explained that the palm oil mill effluent (POME), which is in brownish liquid form, contains large amounts of nitrogenous compounds (Rupani et. al., 2010; Habib et al., 1997). Besides, there are large areas of palm oil plantation near to D5 station. It is also believed that the nitrate accumulated in the soil originating from fertilisers used at the plantation leached out into the nearby river during rainfall, which consistent with studies reported by Neal et al. (2000) and Bellos et al. (2004). Moreover, the river flow was very slow at station $\mathrm{D}_{5}$ in which reduced the dilution process and simultaneously increased the nutrient level.
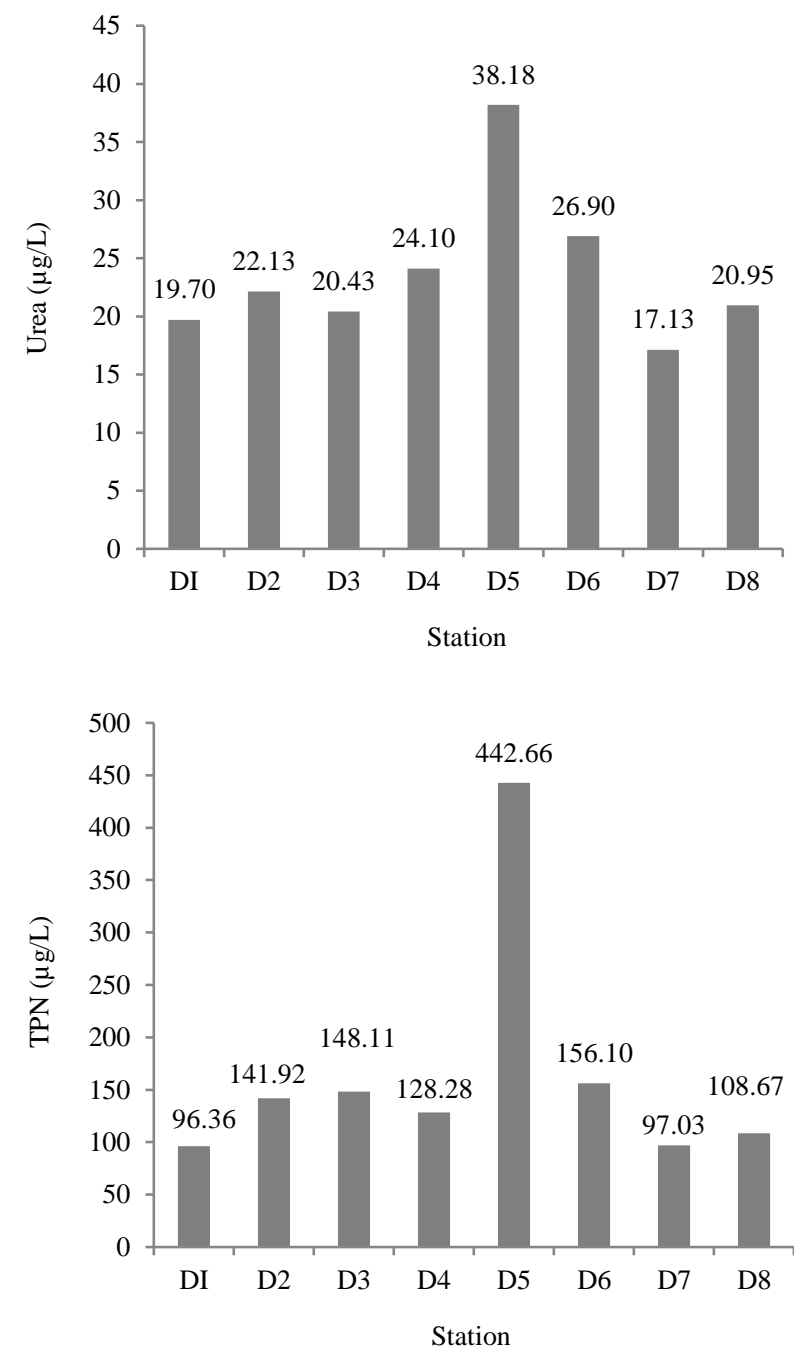

Figure 5. Distribution of mean values for N-based nutrients in each station 
In this study, station D8 recorded relatively high mean concentrations of nitrate $(92.06 \mu \mathrm{g} / \mathrm{L} \mathrm{N})$, ammonia (30.98 $\mu \mathrm{g} / \mathrm{L} \mathrm{N})$, and TDN (232.10 $\mu \mathrm{g} / \mathrm{L} \mathrm{N})$. This occurrence was due to the station being located near to the estuary where nutrients tend to accumulate. Sand-digging activities, which were active near station D8, may have also contributed to the nutrient input. Station D7 showed relatively high nitrate mean concentrations due to the point source discharge from the water treatment plant activity (Bellos et al., 2004) and non-point source runoff from agriculture nearby (Cheung et al., 2003). The result also implied that dissolved organic nitrogen dominated station D6 as the mean nitrate and ammonia concentrations were much lower than the TDP mean concentration. Generally, stations D1, D2, D3 and D4 showed moderate levels of mean concentrations of N-based nutrients, as the stations were located upstream of the river. It was also believed that the source of nutrient input in the river was mainly from domestic waste as the locations were near to villages and residences. Based on the NWQS classification for Malaysia, the nitrate mean concentrations for the Dungun River Basin can be categorised as Class I, indicating a natural level. Class I represents water bodies suitable for the conservation of the natural environment, habitats for very sensitive aquatic species and for water supply with minimal treatment. However, no comparison could be made for urea, TDN and TPN as these parameters were not listed in the NWQS classification for Malaysia.

The comparison of N-based nutrients in the present study with other selected rivers are illustrated in Table 7 . The mean concentrations of nitrate, ammonia and TDN in the Dungun River basin were lower compared to the Marang and Setiu River basins. The higher mean concentrations of these forms of nutrients reported in the Marang and Setiu River basins were most probably due to the input of domestic waste from residences and urban areas, waste from agriculture and aquaculture activities, and surface runoff from the sand mining area. If compared to the Nerus River, the mean concentrations of nitrate in Dungun River were still lower, although the mean concentrations of ammonia were higher. According to Tahir et al. (2005), the main source of nitrate in the Nerus River originated from fertiliser runoff from the palm oil plantation and domestic waste from the residential area nearby.

Table 7. Comparison of N-based nutrients within selected study areas (unit: $\mu \mathrm{g} / \mathrm{L}$ N, “-”: not available)

\begin{tabular}{|c|c|c|c|c|c|c|}
\hline Location & Nitrate & Ammonia & Urea & TDN & TPN & References \\
\hline Dungun River & $50.13-155.96$ & $14.53-69.85$ & $17.13-38.18$ & $164.86-367.82$ & $96.36-442.66$ & $\begin{array}{c}\text { Present } \\
\text { study }\end{array}$ \\
\hline Marang River & $65-426$ & $16-161$ & - & $128-787$ & - & $\begin{array}{c}\text { Suratman and } \\
\text { Tahir (2013) }\end{array}$ \\
\hline Setiu River & 72.8-228.9 & 20.86-105.84 & - & $200.06-512.4$ & - & $\begin{array}{c}\text { Suratman et } \\
\text { al. (2004) }\end{array}$ \\
\hline Nerus River & $27-558$ & $1-22$ & - & - & - & $\begin{array}{l}\text { Tahir et al. } \\
\quad(2005)\end{array}$ \\
\hline
\end{tabular}

\section{Distribution of P-based Nutrients}

The distribution of the mean values of P-based nutrients at each sampling station is illustrated in Figure 6. The following were the ranges of concentrations: orthophosphate 3.25 to 7.53 $\mu \mathrm{g} / \mathrm{L}$ P, TDP 5.03 to $16.18 \mu \mathrm{g} / \mathrm{L} \mathrm{P}$ and TPP 3.28 to 13.00 $\mu \mathrm{g} / \mathrm{L} \mathrm{P}$. The one-way ANOVA test indicated that there were significant differences between the sampling stations for all P-based nutrients $(\mathrm{p}<0.05)$. In this study, the highest concentrations of orthophosphate, TDP and TPP were recorded at station D5 (orthophosphate: $7.52 \mu \mathrm{g} / \mathrm{L} \mathrm{P}$; TDP:
16.18 $\mu \mathrm{g} / \mathrm{L} \mathrm{P}$; TPP: $13.00 \mu \mathrm{g} / \mathrm{L} \mathrm{P}$ ). These findings were similar to the N-based nutrients results; thus, the source of the nutrient input was related. It is believed that the effluent from the palm oil factory and fertiliser runoff from the palm oil plantation contributed to the increment of the concentration of P-based nutrients at that station. Meanwhile, the TPP mean concentration was relatively higher at station D6 (11.74 $\mu \mathrm{g} / \mathrm{L}$ P), most probably due to shoreline erosion and resuspension of sediment (Kawasaki et. al., 2016; Mayer et al., 1991). This result was in agreement with the TSS data, whereby the TSS mean value at station D6 was relatively high 
compared to other stations. According to the NWQS for because these parameters were not listed in the NWQS Malaysia, orthophosphate concentration in the Dungun River classification for Malaysia.

basin was classified as Class I, indicating a natural level.

However, no comparison could be made for TDP and TPP
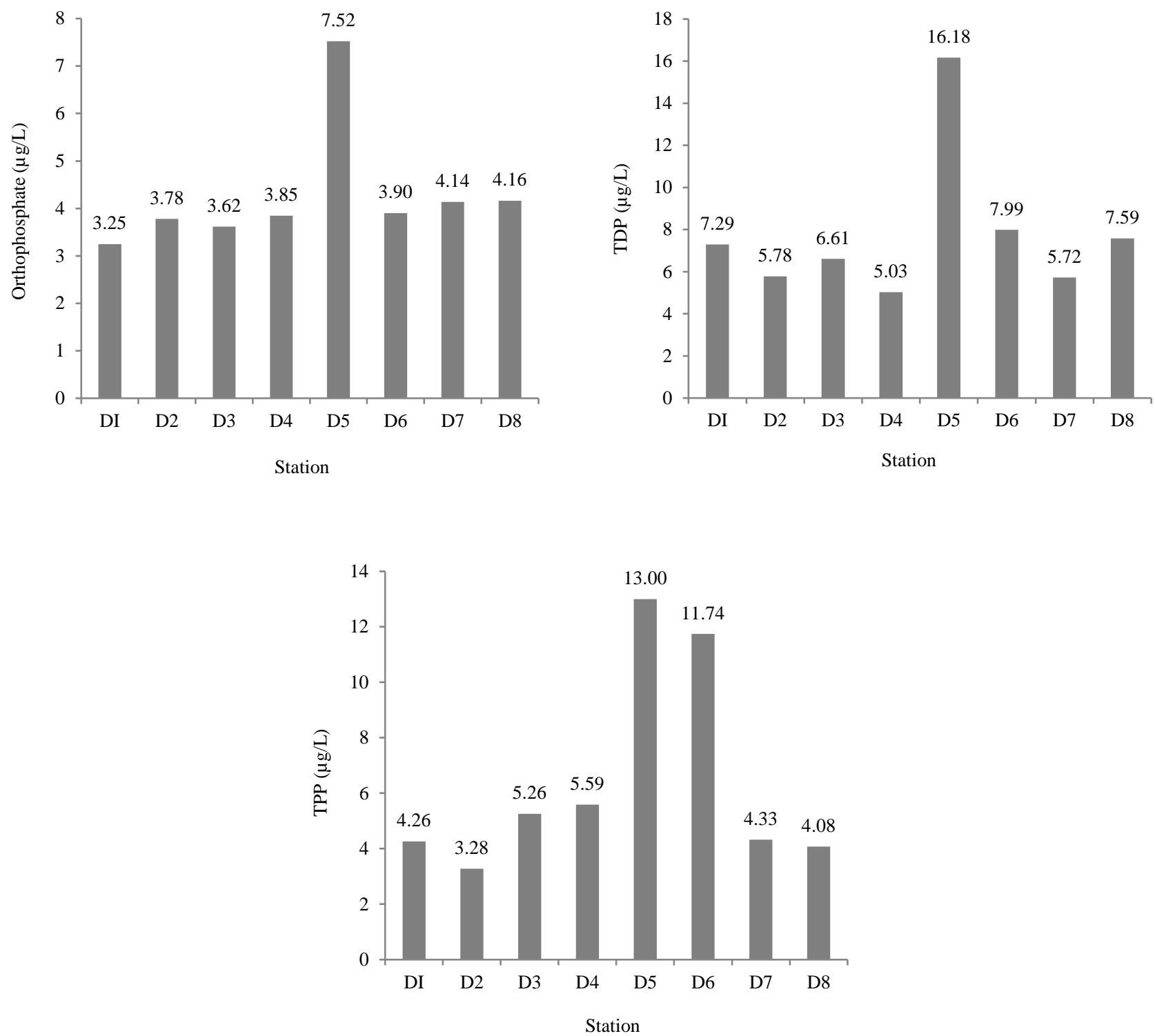

Figure 6. Distribution of mean values for P-based nutrients in each station

The comparison data for P-based nutrients are illustrated in Table 8. In general, all selected previous studies have higher ranges of P-based nutrient concentrations compared to the Dungun River basin. In the Setiu River and Nerus River basins, a slightly higher range of P-based nutrients were most likely due to domestic sewage from nearby towns and palm oil plantation fertilisers (Tahir et. al., 2005; Suratman et al., 2004). As reported for the Marang River basin, the most likely source came from animal farm effluent discharge, fertiliser runoff from agricultural sites, and soil erosion (Suratman \& Tahir, 2013). 
Table 8. Comparison of P-based nutrients within selected study areas (unit: $\mu \mathrm{g} / \mathrm{L} \mathrm{P,} \mathrm{“-”:} \mathrm{not} \mathrm{available)}$

\begin{tabular}{c|c|c|c|c}
\hline Location & Orthophosphate & TDP & TPP & References \\
\hline Dungun River & $3.25-7.52$ & $5.03-16.18$ & $3.28-13$ & Present study \\
Marang River & $27-62$ & $55-105$ & - & Suratman and Tahir (2013) \\
Setiu River & $1.02-6.85$ & $9.21-23.59$ & - & Suratman et al. (2004) \\
Nerus River & $5-22$ & - & - & Tahir et al. (2005) \\
\hline
\end{tabular}

\section{E. N:P Ratio and Trophic State Classification}

In this study, the ratio of $\mathrm{N}: \mathrm{P}$ was calculated as the ratio of mean nitrate to mean orthophosphate for each sampling station, using values based on mass (Table 9). Thus, the "Redfield ratio" for atomic molar N:P of 16:1 corresponded with a N:P mass ratio of 7.2:1. From the calculation, the ratios along the Dungun River ranged from 12.9:1 to 27.7:1. This range showed that all the sampling stations had higher $\mathrm{N}: \mathrm{P}$ ratios compared to the reference ratio (7.2:1) which implies that all of the stations had P-based nutrients as the limiting factor. Based on this calculation, the overall N:P mean ratio (by weight) for the Dungun River was 19.8:1, which was higher than the "Redfield ratio" (7.2:1). This indicated that the phytoplankton growth in the Dungun River was generally controlled by P-based nutrients (orthophosphate). This finding was in parallel with the mass N:P ratio reported in freshwater systems such as the Selangor River (12:1) (Suratman et al., 1999) and the Setiu River (40:1) (Suratman et al., 2004), which also preferred the same nutrient as the limiting factor. However, the N:P ratio in the Setiu River was much higher compared to this study area due to the high level of nitrate in the Setiu River.

Table 9. Ratio of mean nitrate to mean orthophosphate

$(\mathrm{N}: \mathrm{P})$ for each station

\begin{tabular}{c|c|c|c}
\hline Station & $\begin{array}{c}\text { Nitrate } \\
(\boldsymbol{\mu g} / \mathbf{L} \mathbf{N})\end{array}$ & $\begin{array}{c}\text { Ortho- } \\
\text { phosphate } \\
(\boldsymbol{\mu g} / \mathbf{L} \mathbf{P})\end{array}$ & $\begin{array}{c}\text { N:P ratio } \\
(\mathbf{b y} \text { mass })\end{array}$ \\
\hline D1 & 90.10 & 3.25 & $27.7: 1$ \\
D2 & 64.35 & 3.78 & $17.0: 1$ \\
D3 & 65.49 & 3.62 & $18.1: 1$ \\
D4 & 70.33 & 3.85 & $18.3: 1$ \\
D5 & 155.96 & 7.52 & $20.7: 1$ \\
D6 & 50.13 & 3.90 & $12.9: 1$ \\
D7 & 87.67 & 4.14 & $21.2: 1$ \\
D8 & 92.06 & 4.16 & $22.1: 1$ \\
\hline
\end{tabular}

Table 10. Total P-based (TP) nutrient (TDP + TPP) for each station (unit: $\mu \mathrm{g} / \mathrm{L} \mathrm{P}$ )

\begin{tabular}{c|c|c|c}
\hline Station & TDP & TPP & TP \\
\hline D1 & 7.29 & 4.26 & 11.55 \\
D2 & 5.78 & 3.28 & 9.06 \\
D3 & 6.61 & 5.26 & 11.87 \\
D4 & 5.03 & 5.59 & 10.62 \\
D5 & 16.18 & 13.00 & 29.18 \\
D6 & 7.99 & 11.74 & 19.73 \\
D7 & 5.72 & 4.33 & 10.05 \\
D8 & 7.59 & 4.08 & 11.67 \\
\hline
\end{tabular}

The trophic state for the Dungun River Basin was classified based on its limiting nutrient concentration (P-based nutrients). The existing state of classification oligotrophic, mesotrophic, eutrophic and hypereutrophic correspond for total phosphorous (TP) nutrients to <12, 12-24, 24-96 and $>96 \mu \mathrm{g} / \mathrm{L}$, respectively (Carlson \& Simpson, 1996). In this study, utilised TP nutrient refers to the sum of TDP and TPP (Table 10). The mean TP nutrient along the Dungun River ranged between 9.06 and 29.18 $\mu \mathrm{g} / \mathrm{L}$ P. Moreover, the overall mean TP was $14.22 \mu \mathrm{g} / \mathrm{L} \mathrm{P}$ and therefore classified Dungun River Basin in the mesotrophic class. This also indicated that the Dungun River Basin generally had an intermediate level of productivity.

\section{CONCLUSION}

The major source of pollutants in the Dungun River basin was identified at the station near to the palm oil factory and plantation. The effluent discharge and fertiliser runoff from that area had degraded the water quality as indicated by the $\mathrm{pH}, \mathrm{DO}, \mathrm{BOD}, \mathrm{COD}$, and TSS values. In fact, the mean concentrations of N-based and P-based nutrients were also higher near this area. Based on the Malaysia NWQS classification, the mean values of water quality parameters were classified as Class I (DO and ammonia), Class II (BOD 
and TSS) and Class III (COD and $\mathrm{pH}$ ). However, the nitrate and orthophosphate mean concentrations in the Dungun River basin were still classified as Class I, which indicated a natural level. The WQI mean value in the Dungun River basin was $85.44 \%$ (Class II) and this can be considered that the river was clean with minimum pollution. Based on the mass $\mathrm{N}: \mathrm{P}$ ratio, the overall N:P ratio for the Dungun River Basin was 19.8:1, which was higher than the proposed Redfield ratio (7.2:1). This indicated that the phytoplankton growth in this river was generally controlled by P-based nutrients. In this study, the sampling and monitoring period was only carried out across four months. Thus, in order to interpret the real status of the study area, a longer assessment period should be undertaken. It is also suggested that monitoring should be carried out continuously for proper management of this river basin.

\section{REFERENCES}

Ahmad, AL, Ismail, S \& Bhatia, S 2003, 'Water recycling from palm oil mill effluent (POME) using membrane technology', Desalination, vol. 157, pp. 87-95.

Apha 1995, Standard Methods for the Examination of Water and Wastewater, 19th edn, Washington: APHA, AWWA \& AWPFC.

Bellos, D, Sawidis, T \& Tsekos, I 2004, Nutrient chemistry of River Pinios (Thessalia, Greece), Environment International, vol. 30, pp. 105-115.

Binh Thanh, N, Vo, LD, Nguyen, TX \& Quang, NX 2020, 'The interactive effects of natural factor and pollution source on surface water quality in the lower Mekong River Basin, Southwestern Vietnam', Water Resources, vol. 47, pp. 865876.

Bordalo, AA, Teixeira, R \& Wiebe, WJ 2006, 'A water quality index applied to an international shared river basin: the case of the Douro River', Environmental Management, vol. 38 , pp. 910-920.

Chapman, D 1992, Water quality assessments: A guide to the use of biota, sediments and water in environment monitoring, 1st edn, London: Chapman \& Hall.

Cheung, KC, Poon, BHT, Lan, CY \& Wong, MH 2003, 'Assessment of metal and nutrient concentrations in river water and sediment collected from the cities in the Pearl River Delta, South China', Chemosphere, vol. 52, pp. 14311440.

Chungsiriporn, J, Prasertsan, S \& Bunyakan, C 2006, 'Minimization of water consumption and process optimization of palm oil mills', Clean Technologies and Environmental Policy, vol. 8, pp. 151-158.

Doe 2006, Department of Environment Malaysia: Malaysia Environmental Quality Report, Kuala Lumpur, Malaysia.
Effendi, H, Romanto \& Wardiatno, Y 2015, 'Water quality status of Ciambulawung River, Banten Province, based on pollution index and NSF-WQI', Procedia Environmental Sciences, vol. 24, pp. 228-237.

Grasshoff, K, Ehrhardt, M \& Kremling, K 1983, Methods of Seawater Analysis, 2nd edn, Weinheim: Verlag Chemie.

Habib, MAB, Yusoff, FM, Phang, SM, Ang, KJ \& Mohamed, S 1997, 'Nutritional values of chironomid larvae grown in palm oil mill effluent and algal culture', Aquaculture, vol. 158, pp. 95-105.

Hee, YY, Suratman, S \& Weston, K 2020, 'Nutrient cycling and primary production in Peninsular Malaysia waters; regional variation and its causes in the South China Sea', Estuarine, Coastal and Shelf Science, vol. 245, pp. 106947.

Ho, KC, Chow, YL \& Yau, JTS 2003, 'Chemical and microbiological qualities of The East River (Dongjiang) water, with particular reference to drinking water supply in Hong Kong', Chemosphere, vol. 52, pp. 1441-1450.

Jonnalagadda, SB \& Mhere, G 2001, 'Water quality of the odzi river in the eastern highlands of Zimbabwe', Water Research, vol. 35, pp. 2371-2376.

Kawasaki, N, Kushairi, MRM, Nagao, N, Yusoff, F, Imai, A \& Kohzu, A 2016, 'Seasonal changes of nutrient distributions along Selangor River, Malaysia', International Journal of Advances in Chemical Engineering and Biological Sciences, vol. 3, no. 1, pp.113-116.

Lata, K, Kansal, A, Balakrishnan, M, Rajeshwari, KV \& Kishore, VVN 2002, 'Assessment of biomethanation potential of selected industrial organic effluents in India', Resources, Conservation and Recycling, vol. 35, pp. 147-161. Ling, TY, Lee, TZE \& Nyanti, L 2013, 'Phosphorus in Batang Ai hydroelectric dam reservoir, Sarawak, Malaysia', World Applied Sciences Journal, vol. 28, pp. 1348-1354. 
Mayer, T, Kuntz, KW \& Moller, A 1991, 'Total and bioavailable particulate phosphorus loads from the Niagara River in 1987 and 1988', Journal of Great Lakes Research, vol. 17, pp. 446-453.

Navarrete, IA, Tee, KAM, Unson, JRS \& Hallare, AV 2018, 'Organochlorine pesticide residues in surface water and groundwater along Pampanga River, Philippines', Environmental Monitoring and Assessment, vol. 190, 289.

Neal, C, Williams, RJ, Neal, M, Bhardwaj, LC, Wickham, H, Harrow, M \& Hill, LK 2000, 'The water quality of the River Thames at a rural site downstream of Oxford', Science of The Total Environment, vol. 251-252, pp. 441-457.

Rupani, PF, Singh, RP, Ibrahim, MH \& Esa, N 2010, 'Review of current palm oil mill effluent (POME) treatment methods: Vermicomposting as a sustainable practice', World Applied Sciences Journal, vol. 10, pp. 1190-1201.

Suratman, S, Awang, M, Loh, AI \& Tahir, NM 2009, 'Kajian indeks kualiti air di lembangan Sungai Paka, Terengganu', Sains Malaysiana, vol. 38, no. 2, pp. 38, 125-131.

Suratman, S \& Tahir, NM 2013, 'Kesan antropogenik terhadap kualiti air di lembangan Sungai Marang, perairan selatan Laut China Selatan', Sains Malaysiana, vol. 42, pp. 743-751.

Suratman, S, Tahir, NM, Lee, CY \& Rashid, SRA 2006, 'Kesan monsun terhadap kualiti air di lembangan Sungai Besut, Terengganu', Malaysia Journal of Analytical Sciences, vol. 10, pp. 143-148.

Suratman, S, Tahir, NM \& Suriyati, S 2004, 'Dissolved nutrients and chlorophyll a status of the Setiu River, Terengganu, Malaysia', Bulletin of Environmental Contamination and Toxicology, vol. 73, pp. 1094-1100.

Tahir, NM, Suratman, S, Jusoh, SR, Yahaya, SN, Yusoff, N M \& Theem, LA 2005, 'Penentuan indeks kualiti air dan nutrient terlarut di Sungai Nerus, Terengganu', Malaysian Journal of Analytical Sciences, vol. 8, pp. 193-197.

Ying, L, Jiao, M \& Yong, L 2012, 'Analysis of Eutrophication of Yangtze River Yibin Section', Energy Procedia, vol. 16, pp. 203-210.

Zaideen, IMM, Suratman, S \& Tahir, NM 2017, "The evaluation of spatial variation of water quality in Sungai Setiu Basin, Terengganu', Sains Malaysiana, vol. 46, pp. 1513-1520. 